\title{
Money and Labour as Socio-economic Categories
}

\author{
Andrey Orekhov \\ Department of Social Philosophy \\ Peoples' Friendship University of Russia \\ Miklukho-Maklay str., 10/2, Moscow, Russia, 117198 \\ E-mail: orekhovandrey@yandex.ru
}

\author{
Fakhraddin Akhmedov \\ Department of Finance and Credit \\ Peoples' Friendship University of Russia \\ Miklukho-Maklay str., 10/2, Moscow, Russia, 117198 \\ E-mail: akhmedov@mx.rudn.ru
}

\begin{abstract}
The article considers the concepts of "money" and "labour" in the light of the categorical analysis in economic science. "Money" and "Labour" are socio-economic categories; consideration of each of them is possible only within the requirements of the interdisciplinary approach connecting an economic science. For the analysis of money as a social institute, it is necessary to formulate the new "social philosophy of money" which considers it as a social, and not just as a financial institution. Labour also is a social institution; when functioning it is closely connected with other fundamental institution - with property, freedom and justice. In the postindustrial society, labour will change from maintenance; it will transform into creative activity.
\end{abstract}

Keywords-money; labor; Categorical analysis; PostIndustrial society

\section{INTRODUCTION: CATEGORICAL ANALYSIS IN ECONOMIC SCIENCE}

The categorical analysis of economic science demands close attention in concern to its' basic categories and the possible meaning of economic terms and their interpretation. The necessity of such analysis consists of many economic terms and categories which have multiple meanings. It is therefore always important for an economist to specify the meaning of any concept used, which will help to clarify its theoretical constructions. The categorical analysis in economic science, as a result, brings us to the creation of «analytical economic science» based on the analysis of economic language and clarifies the meaning of every «economic rhetoric».

One of the most famous economists investigating the problems of economic rhetoric is the American economist D.Makkloski. However, it is necessary to notice that he understands "economic rhetoric" as an art of eloquence used by economists. But such an approach does not exclude; on the contrary, it insists on careful categorical analysis.

The rhetoric is understood as the study and application of convincing formulations and expressions, having existed since Ancient Greece as an alternative to the philosophical program of epistemology. The rhetoric of an economic science is engaged in the research of a question on how economists convince. How they (or their official methodologists), describe it, and how actually they convince politicians, students or colleagues to accept one theory and to reject another. The rhetoric of an economic science demands the correctness of differentiation of the natural sciences and the humanitarian argumentation. It does not aspire to attack quantitative methods or to bring an irrationality element to the exact sciences, but tries to realize science as conversation. It aspires to lift this conversation to a higher level and to make it more adequate. [5. P.748-750].

Thus, categorical analysis in economic science should result in clearing economic concepts and promoting further specification and verification of economic language and, as a whole, the economic science.

\section{MONEY AS A SOCIO-ECONOMIC CATEGORY}

The last financial and economic crisis (2008-2011) once again underlined the structural role of money in conditions of the modern postindustrial society.

In such a situation, it will be quite pertinent to raise the question about new social philosophy of money - the philosophy reflecting the realities of the postindustrial world and an epoch of globalization. To begin with, nevertheless, we will try to distinguish the social philosophy of money from the theory of money1.

The theory of money is an economic doctrine about money, about monetary circulation and, as a whole, about the financial sphere of economy. This is the doctrine of how money functions in a society and the financial sector of economy on a global scale. Arguments of the theory of money, as a rule, are expressed in economic-mathematical language, supported with strict systems of proofs and verified by the empirical facts and examples.

The philosophy of money is a philosophical-economic doctrine about the essence of money and includes the metaphysical and ontological bases of a modern monetary economy, where money is a philosophical-economic entity that has a deep impact on the development of the economy and all public life. As a philosophical-economic entity, money has a set of functions and purposes that cannot be reduced completely to traditional economic functions (money as a currency, accumulation means, etc.). Besides purely economic functions, money has also various social functions. As a whole, the quantity of social functions of money are so great that it is necessary to become isolated on one or several of them; always there is a risk of losing sight

\footnotetext{
${ }^{1}$ Some ideas have been stated by us earlier [11]
} 
of even more significant social functions: "Money is a system with incomplete unification; search of one purpose of use of money conducts in deadlock. It is useless to attempt defining «the nature and sense» of money. These purposes arise from the situation in which we use the given subjects and the analysis of result of this use" [12. P.89].

It is possible to express the same thesis as follows: from the philosophical-economic point of view, money should be considered not only as a purely economic institute but also as social institute. The research of money as social institute should be based on the tools of various sciences: economics, sociology, political science, cultural science, history, etc. Philosophy should also play a key role as a general methodology of all social sciences here; it should synthesize and generalize the received results of private disciplines. It is natural that the priority will be given, nevertheless, to the conclusions received by economic science, and, in particular, conclusions, which stem directly from the theory of money; all final conclusions, however, will be made using the philosophy of money.

The modern philosophy of money considers sets of various problems, for example, the symbolization of money, fetishism of money and a monetary economy, virtualization of money and finance, the social and cultural value of money, the problem of the "alienation" of money from the person etc. The philosophy of money also urges the discussion of both such not palatable and obscure question for economists, as a question on "the end of money". Whether there will be money or even a social institution of money in the future remains to be seen. Meanwhile, only science fiction writers know the answer to this question, but economists and philosophers guess and assume2.

On each of these questions there is a history and the authorities. In particular, many economists mentioned a problem of symbolism of money. K.Polani, for example, here marked the following: "Thus, money in XIX [and also in XX and XXI centuries-A.O., F.A.] century represent exchange symbols; it is used for the various purposes and acts almost in a perfect analogy with language and writing where sounds and signs are till now universal money" [12. P.93].

Other authors give as a good analogy between money, on the one hand, and language, on the other hand, and this analogy allows one to connect two modern swift-flowing processes - the symbolization of money and their transformation in the media, communicative tool, - like the Internet, newspapers and TV, - handing over the information from the person to person.

2 The Soviet writer Schefner V. in his fantastic story A Girl near Precipice has a small reasoning about it, a reflection from the future: "My story begins that day when they have cancelled money. ...In effect, anything special this day hasn't occurred. The matter is that a process of dying of money went for a long time. Money hasn't died suddenly, they have quietly died... Lately they mattered rather statistical, than valuable. If you lacked bank notes for purchase of a thing necessary to you, you just pulled out a leaf from the notebook and wrote on it " 15 kopeks" or " 3 rubles" and paid them to the shop assistant. Or you just could ask money from any passerby, and he gave you the required sum and, without asking your name, went the own way" [14. P.11].
The symbolization of money is closely connected with a problem of the fetishization of money and its transformation into a general communicative means: "Money becomes the universal intermediary in relations of a market exchange because it is deprived qualitative definiteness, it is only a universal sign which can accept any appearances, turning into both material, social, and even cultural wealth. Therefore, money possesses the property to gradually integrate into all spheres of human life. But thus according to the invariable nature money introduces everywhere and alienation element" [17. P.321].

The following interesting point in the social philosophy of money is a problem with a substance of money, its fundamental principle, the primary source. Naturally, from the point of view of classical political economy, the question on the substance of money should be connected with cost (value), and further with sources of this cost (value) - labour, capital, natural resources, enterprise ability. However, it is a sight from the point of view of the theory of money.

The social philosophy of money should put this problem in much more extensive terms, and, as we say, the "holographic" prospect. For example, it is interested in whether this substance of money flows or, on the contrary, is motionless; if money during the various periods of time (distracting, certainly, from inflation) is equal or is not equal, and how money and time as a whole are connected, whether it is possible concerning money to put a problem of coincidence of essence and existence like Heidegger 3 etc. All these are questions which can be designated as the "metaphysics of money".

Some authors already tried to answer anyhow these questions, and strangely enough, among them there are not economists, but rather philosophers and lawyers: "If trying to catch a substance of money, we can notice that money unlike any other thing appears a subject to time's influence (we here distract from a problem of deterioration and improvement) and obviously is not equal to itself during the different moments: it rather falls in value, or "grows", without changing the material nature, thus, any strong taking of money does not provide domination over its' essence. It remains till the end a subject neither the owner, nor the proprietor. Hence, the absoluteness of the right is forfeited; it appears dependent on a turnover, on a society as a whole" [15. P.431].

"Money as a medium circulates and does not disappear anywhere; being the medium of communications and stable in time, it is a measure and motivation of all economic activities: if buying and selling for the sake of money and by means of money payment makes sense and possesses rationality in a context of economic system, it belongs to this system" [2. P.37].

How has the modern philosophy of money estimated the role of money and the financial sphere as a whole in economic system?

\footnotetext{
${ }^{3}$ Martin Heidegger (1889 - 1976) - German philosopher
} 
Let's begin with a well-known metaphor: "finance is economy's blood". Sometimes they assert that such statement unduly overestimates the role of money and the finance in economy. In our opinion, on the contrary: there takes place not revaluation, but underestimation of the role of the financial sphere in the general structure of a modern economy.

One can even say more rigidly: "Finance is not only the blood, but also the heart and the brain of the economy" 4 .

The role of money in economy considerably changes, but simultaneously changes also economy itself. The economy becomes a "financial economy", "finance dependent economy". We recognize it or not, but it so. Value of money and the finance has sharply increased in modern economy, and the modern philosophy of money underlines this fact day and night.

It is natural that the attitude in a modern economic science is a miscellaneous, and negative enough. It is possible to give J.M.Osipov's statement as an example of sharply negative characteristic of modern «financomics»: "Money, at last, is created by the economy though it exists not only for the economy, but also for itself; that is why an economy depends on money. Here we have a phenomenon of total financizm, if under the finance we mean in general any working money, with application and such ostensibly neutral "features", as rates of exchange. In a global financial system all means are good and the main thing realized is a financial and cost control over the economic environment. Here we deal not simply with the economy, but with a financial economy, and, for brevity, with "financomics". Financomics is a total domination of money being in exclusively elite possession and given on credit to not elite... [1. P.30-31].

We categorically would disagree with so destroying characteristics of "financomics". To condemn the modern economy for gradually turning into "financomics" is the same as accusing a caterpillar of transforming into a butterfly. After all the main objectives of the economy, it "corner senses", i.e. stability, economic growth, economic efficiency, economic justice, unemployment and inflation decrease, etc., - in any way are inherently not connected with a role of finance in the economy. Alternatively, we will tell that these purposes can be reached or by means of economic transformation in "financomics", or without this, the main thing is that they have been reached. If "financomics" will resolve all economic problems more effectively than classic economics, we should follow it.

Nevertheless, in J.M.Osipov's reasoning there is also one more argument: of which he accuses "financomics", which is the "total domination of the money being in exclusively elite possession and given on credit not elite". However, it is hardly possible to recognize such argument as serious from the scientific point of view: it is an argument from common sense-"ordinary consciousness". In the practical development of the financial sphere and credit-bank system

\footnotetext{
${ }^{4}$ But what then all other spheres? They are - other «bodies»: stomach, lungs, liver, kidneys, etc.
}

(apparently, J.M.Osipov means) conducts absolutely contrary results: decreasing the level of social inequality in a society, softening social problems, and increasing the wellbeing of the population.

We can agree with J.M.Osipov that in "financomics" there are separate disproportions, but not necessarily more than in a "non-financial economic system", and they are connected more likely not with "financomics", but with a human nature as a whole: "If there are lacks in financial system, they are reflexion of human nature. ...In effect, growth and recession are products of our emotional instability" [1. P.23].

Hence, as money so the finance are indifferent concerning key economic targets and problems. Nevertheless, money as the right of use for any resources, the possibilities of application of any factors, is either the animator pushing the economy forward, or the fifth wheel", braking it. Therefore, it is necessary to underline once again: "We require a set of money - both good and different. And the most important thing that is necessary to remember: money is not banknotes, silver or gold-- money is possibility of people to trust each other, or, we say so, 'a purchasing sign on trust', opening to people the diversified possibilities of dialogue and communications. The modern social philosophy of money also specifies: the role of money and a monetary economy in a modern economic science is more likely underestimated, than overestimated. Any more money has begun not only the economy's blood of XXI century, but also the heart and brain of this economy.

Moreover, it is silly to expect that the recent financial crisis (2008-2011) will be the last in the history of mankind. Crises still will happen, and it is necessary to be ready. The most important thing is to learn to expect them (though to be ready one week or two prior to their approach), and then when nevertheless crisis comes, to pass a crisis phase as much as possible without serious consequences and without serious social and economic cataclysms. In this aspect the new philosophy of money and the new interpretation of money as a socio-economic category should play a considerable role.

\section{LABOUR AS SOCIO-ECONOMIC CATEGORY}

Life is going on; new realities at the beginning of the XXI century have been put before scientists (economists, philosophers, sociologists, political scientists) and new problems concerning a place and value of labour in a modern society have arisen. However, with a considerable regret authors of the given article are compelled to ascertain that nowadays "the labour" problem is rejected on the periphery of modern socio-economic researches. That, in turn, is negatively reflected in publications on the given theme, and by the number of scientists who develop it.

What problems connected with labour are actually from the point of view of a modern economic epoch - the epoch of a postindustrial information society?

First, it is a problem of designing a modern definition of labour, specifically a labour and leisure distinction. 
Secondly, it is a problem of freedom of labour and socalled problem "the rights to labour".

Thirdly, it is a question on "fair" and "unfair" labour, liquidation of all forms closely connected with the question of "economic discrimination" and "exploitation".

Moreover, fourthly, it is a problem of the future labour, which can be designated as "futurolabour".

Let's discuss all four these problems one after another.

The concept of "labour" in an economic science has two meanings:

- Labour is expedient, almost useful activity in the creation of material and spiritual (intellectual) blessings. "Labour is the efforts spent on the creation of a new thing, with new appointments which, forming passively, are 'rough' material to the manufacturer" [16. P.65].

- Labour is a specific resource (factor) with which "land", "capital" and "enterprise ability" participates in value creation, and the income on the given resource is wages.

The first of these two definitions is most suitable to use as "philosophic-economical" research, but the second has exclusively narrow meaning applied only in the theory of "economic resources (factors)",- - therefore with the first of these definitions we will operate further.

Leisure is traditionally opposed to labour. Leisure is human activity of regenerative character; its purpose is to prepare the person for the subsequent labour activity5.

Leisure can be appear in various forms: game, sports, travel, study, passive contemplation, a dream, etc. Study, sports, and games to a certain extent prepare labour; for example, business game forms an economic thinking in the student-economist and promotes his maturing as a future analyst, businessperson or financier.

Correlating the definition of labour to its daily and empirical characteristics, it is necessary to pay attention to the fact that there are two debatable kinds of the activity with reference to "labour". It is a question of criminal activity and war as an occupation.

Criminal activity is the activity directed on the infringement of the laws of a society, accompanying various forms of other encroachments - on a human life, the property, etc. Criminal activity is parasitism, original anti-labour.

The "war" definition through the lens of labour also can be made based on the concept of "military labour", reflecting specificity of the labour of military men. Whether one can consider as "labour" activity of one individuals directed to destruction of other individuals? Most likely, the concept of "military labour" represents an oxymoron - the contrast combination of two words breaking semantic unity. Probably also use of other term- "pseudo-labour", as the kind of

\footnotetext{
${ }^{5}$ It shouldn't be taken literally. Some individuals «prepare» for work all the life, but don't begin it.
}

activity which only formally is labour. If one considers "war" as a special kind of activity which does not coincide with "labour", then it is necessary to contrast it to "labour" along with "leisure". As a result, we will have three principal views of human activity: labour, leisure and war.

War, hunting and some other forms of employment can also act as the forms of certain status behavior connected with demonstrative abstention from labour. Labour, in that case resists "valorous activity", combined with idleness. As believed N.Veblen, such a style of behavior was characteristic for ruling classes during the historical epoch and previous capitalism: "Demonstrative abstention from labour becomes, thus, a traditional sign of the superiority in monetary successes and the standard exponent of the deserved honour. On the contrary, as diligence in productive labour is a sign of poverty and submission, it becomes incompatible with prestigious positions in a society. Abstention from labour traditionally testifies to a solvency and, hence, is the conventional indicator of position in a society". [16. P.85-88].

Let's try to correlate now the concepts of "labour", "leisure" and "war" with concepts of "labour", "anti-labour" and "pseudo-labour": 


\begin{tabular}{|c|c|c|c|}
\hline & $\begin{array}{c}\text { Labour is the expedient, } \\
\text { useful activity that } \\
\text { creates material and } \\
\text { spiritual (intellectual) } \\
\text { blessings }\end{array}$ & $\begin{array}{c}\text { Anti-labour is expedient } \\
\text { activity that draws harm } \\
\text { and causes physical and } \\
\text { mental cruelty both to a } \\
\text { society as a whole, and to } \\
\text { separate individuals }\end{array}$ & $\begin{array}{c}\text { Pseudo-labour is expedient, } \\
\text { formally useful activity, but } \\
\text { from the substantial party } \\
\text { causing a damage and harming } \\
\text { other individuals }\end{array}$ \\
\hline $\begin{array}{c}\text { Labour is expedient, almost useful } \\
\text { activity on creation of the material } \\
\text { and spiritual (intellectual) blessings }\end{array}$ & $\times \times \times$ & $\times$ & $\times \times$ \\
\hline $\begin{array}{c}\text { War is the organized expedient } \\
\text { activity of one individuals directed } \\
\text { toward the destruction or enslavement } \\
\text { of other individuals }\end{array}$ & $\times \times$ & $\times \times$ & $\times \times \times$ \\
\hline $\begin{array}{c}\text { Leisure is the human activity of } \\
\text { regenerative character; its purpose } \\
\text { to prepare the person for the } \\
\text { subsequent labour activity }\end{array}$ & $\times$ & $\times \times \times$ & \\
\hline \begin{tabular}{c} 
\\
\hline
\end{tabular} & & \\
\hline
\end{tabular}

Let's specify once again the basic social and economic functions of labour in society. The first function of labour is obvious - labour creates costs in society. This function can be named "productive". But it is not a unique function of labour. Labour is the major organizing factor of a human society: it brings harmony, justice and freedom into society. Labour is the guarantor of the property and economic freedom equal for all managing subjects. Labour has also a creative function, it gives a sense to creativity, forms the person, directs his creative activity for the blessing of all mankind. Valuing not only creativity itself, and, first of all, that creativity of the creating person which brings benefit to other people and all mankind. Creative labour brings the spiritual beginning in public consciousness, and the society becomes spiritual and educated.

Labour as a certain social-economic and politicaleconomic process in its functioning is closely connected with other fundamental institutes, first of all, with property, freedom and justice.

For property "the justification" problem through labour, in particular, is very important. If the proprietor manages to prove that the property is labour based, nobody will dare to challenge the given property and to believe it as illegitimate6.

Let's notice also that this way of "justification" of the property convincingly enough admits traditions, morals, and rights. But methods of acknowledgement of these three institutes are various: the tradition simply trusts the subject asserting that he by means of labour has seized any property; the morals demand certificates of respectable persons; and the right insists either on such certificates made in the image

${ }^{6}$ This type of «justification» goes from John Locke. He wrote in the work «Two treatises about board» (1690): «It [labour] adds to them [to land] something in excess of what the nature, the general mother of everything, has created and, thus, they became his private law»; «labour has approved property on them»; «the ground having such sizes that one person can plow, sow, fertilize, cultivate it and consume his product, makes property of people» [10. P.277-279]. established under the law, or on material (for example, written) proofs concerning these labour and the property, - at their absence lawyers, turn a back to the prospective owner of the property.

The right to labour is a version of economic human rights 7 . Such rights guaranteed by the state and society a possibility to freely dispose of major factors of an economy for the purpose of satisfying each person's requirements.

The right to labour is guaranteed by all international certificates about human rights. For example, "The General declaration of human rights" (1948) comprises article 23 which affirms:

- "Each person has the right to labour, a free choice of labour, fair and favorable labouring conditions and protection against unemployment.

- Each person, without any discrimination, has the right to equal payment for equal labour.

- Each worker has the right to the fair and satisfactory compensation providing worthy person existence for him both his family and supplemented, if necessary, by other means of social security.

- Each person has the right to create trade unions and to enter into trade unions for protection of the interests" [8. P.42].

Freedom as a special social institute and also has key value for labour functioning as political-economic and socioeconomic process. The concept of "free labour", widely used in various ideologies interpretation, nevertheless, can be shown in the general denominator: free labour is labour within the limits of the borders given by a society, without any pressure and compulsion. In addition, there should be excluded from this definition hired and forced labour.

\footnotetext{
${ }^{7}$ Sometimes these rules in legal and scientific literature are designated as «social and economic» or even just «social».
} 
Certainly, an antipode of free labour is the slave labour, and society has an aversion to it. Unfortunately, it is impossible to consider this revenge completely done,-especially in aspect of so-called "new slavery" - phenomenon of concern exclusively in the modern epoch. "The new slavery" is a characteristic of some developing countries: Thailand, Mauritania, Pakistan and India.

But labour freedom is not only freedom of the person from forced labour. "Free labour" also means legislatively guaranteed and fixed possibility of each person to freely choose a labour kind. But this choice, certainly, is always limited by both certain psychological and physiological limits. There are professions which demand a certain state of health and/or concrete psychological qualities without which a person cannot pursue that occupation. The main thing here is the absence of the political and legal barriers interfering with a free choice of a profession and labour activity.

Economic justice is the conformity of real in economic sphere: distribution of the economic blessings in compliance with the contribution of each individual to a cumulative social production of these blessings.

Economic justice is one of justice subspecies in general, and can be treated as a social blessing (social value) so a social institute. Economic justice mentions distribution not any resources, but only what can be understood as "rare" or "scarce", i.e. which simply does not suffice much on all individuals.

In the economic literature, they allocate two basic types of justice-"communicative" 8 and "distributive justice. Economic justice is based on this classification and concerns the distributive type of justice: "It [distributive justice] deals with justice in economic relations between members of a society: with justice in joint industrial activity, trade, granting of the public blessings. Usually these forms of an exchange (especially if they are carried out voluntary) give the chance for mutually beneficial receptions. Thus distributive justice is justice of structures (arrangements), corresponding benefits influencing distribution between individuals taking into account their alternative costs and expenses of resources (it is necessary to notice that influence on distribution of benefits and the general case means also influence on their manufacture)» [5. P.205].

Economic justice as the socio-economic blessing is a subject satisfying the maximum interests and requirements of the majority of people. In this aspect economic justice also can be accepted (or not) as certain social value (or as simply "value"), i.e. a subject receiving positive (or negative) estimation of set of people, and, finally, all society. But as a whole, it is necessary to notice that the achievement of economic justice (or at least presence of certain strategy in achievement of economic justice) is approved and authorized by a society and the state as one of the purposes of economic development, as the basic and fundamental purpose of the value.

\footnotetext{
${ }^{8}$ Communicative justice is the justice proceeding from equality (proportionality) of the rights and obligations of various parties.
}

To differentiate purely economic justice and social justice in their general understanding from each other is uneasy enough. Economic justice as an economic institute can be treated as a special system of the norms regulating the relation of distribution of the economic blessings and stably reproducing in a society. These norms are designed on the basis of a concrete interpretation of economic justice as certain values or blessings. In the public consciousness there are, as a rule, some interpretations and strategies of achieving economic justice; all other interpretations have, as a rule, an oppositional character.

If there is discrepancy between real and due distribution of the economic blessings, then it is possible to confirm the existence in the society of economic injustice. The recognition of this fact of economic injustice should bring us to ascertaining of existence of one of three processes, characterizing a condition of economic injustice-to exploitation and discrimination-or at once both processes simultaneously.

For example, the Marxist theory of exploitation was actively developed in the second half of the XX century,- - in particular, by the efforts of such scientists like R.Arneson, G.Cohen, J.Roemer [3, 4, 13].

All these thinkers, objecting neoclassic theory, firmly defend that Marxist concept of exploitation have not yet lost the value, and it can be fixed empirically: "Neoclassical theorists assert that each factor of manufacture receives the income corresponding to the payment. But the Marxist position consists in the following: each factor of manufacture demands such compensation that it could be reproduced in that form which is required for manufacture as a whole. If a similar matter 'is postponed' for one of factors, i.e. a certain cost which the given factor 'receives less', it generates considerable problems for the society and as a result the structure of distribution of resources appears 'defective" " [13. P.65].

J.Roemer considers exploitation not as a simple withdrawal of a surplus value by capitalists from hired workers, but in wider foreshortening: as unequal access to means of production. To cease that, it is necessary to "leave" capitalist manufacturing and to "withdraw" one's own "means of production" and own a share of resources. Assignment of a surplus value by capitalists will not be considered as exploitation if it helps to eliminate unequal access to means of production.

As to the further prospects of the theory of exploitation, one possibly should agree with W.Kymlicka's following thesis: "There is deeper injustice underlying exploitation unequal access to means of production. The women deprived of the rights, jobless, hired labourers - all of them in our society suffer from this injustice while capitalists receive benefit from it. Exploitation of labourers by capitalists is only one form, which this distributive injustice can accept. The subordinated position of women and unemployed are other forms, and, judging by struggle of people for reception of hired labour, probably, more pernicious". [9. P.240]. 
If we accept such approach from the uncertain term of "exploitation" it will bring us to a much more concrete and exact scientific concept - "economic discrimination": Economic discrimination is established in a society legislative either a different way of restriction or deprivation of the rights of any economic group or a class.

What is a reason of economic discrimination? The answer to this question is given by R.Ehrenberg and R.Smith: "Theories put forward three basic sources of discrimination on a labour market, each of them is connected with the certain model showing how discrimination is carried out and what its consequences. The first source of discrimination is personal bias of employers, colleagues or consumers who do not like to co-operate with labourers of a certain race or sex. The second basic source of discrimination is the statistical bias when employers transfer certain characteristics of group realized by them on separate individuals. At last, there are models according to which the aspiration to possession and use of exclusive force represents the discrimination reasons" [6. P.463].

The first of these sources, in our opinion, has no direct relation actually to economic discrimination, more likely it directs thought on other types of discrimination: racial (discrimination on the basis of race), gender (discrimination on the basis of sex), ethnic (discrimination on the basis of a ethnicity), etc. really economic discrimination represent only the second and third source, - and the main problem here is monopoly and absence of a fair competition.

In addition, it is necessary to notice that almost all variants of economic discrimination in one way or another appeal to the general concept of human rights established by the world community. For example, if they proclaim human rights on labour, and a certain group of people (unemployed) are deprived this right then it is quite possible to consider them (even taking into account all possible indemnifications and payments) as an economically discriminated group. Another example of economic discrimination is the implicit principle to which some businessmen adhere, employing new people on the enterprise: "last-in, first-out - last employed dismiss the first"; here economic discrimination concerns those "who are employed as the last". Hence, it will be simple to specify "economically discriminated" groups the unemployed, women, labourers without social packages, etc. In general if we manage to prove that any social group or the class is deprived of any economic possibilities, while all other social groups or classes have access to such possibilities (either from a moral or legal point of view) it is not justified and we will prove that the given group or a class are economically discriminated.

Influence of economic discrimination on the worker can be rather considerable: it worsens possibilities and prospects of a business career, leaving him or her only low-paid, monotonous and a hard work: "So, even an insignificant degree of discrimination in the beginning of a labour way can have very essential consequences for all further careers. Though it is extremely improbable, what exactly discrimination on a labour market has generated a traditional division of labour between men and women in a family, discrimination presence, apparently, in many respects promotes preservation of this division" [5. P.380].

Liquidation of various types of economic discrimination is a problem improbably difficult and almost impracticable even for the developed postindustrial states; but strategically this vector should be maintained and understood certainly if not the nearest purpose, but the purpose of a perspective that is certainly achievable in the future.

What is positive in postindustrial labour, and what is the negative?

In the positive aspect, postindustrial labour should become even more technically made; cars and robots will incur all hard labour; it concerns, first of all, industry and agriculture spheres. Relative density of service and management considerably will grow; the introduction of computer and information technology will lead to the occurrence of new professions and activities. The worker in the postindustrial epoch will choose not simply a profession, but a profession which will allows him to open his or her creative abilities and to realize their creative potential. Labour will pass in creativity, creativity will encourage a more multicultural and varied world.

On the other hand, postindustrial labour gives rise also to certain problems, which can be regarded as negative consequences of those processes that occur in a postindustrial society. First, the postindustrial society still has not proved that it can be a just society; on the contrary, many theorists of a postindustrial wave notice the fact that the differentiation and polarization grows in this type of society. For example there is a middle class disintegration. Secondly, "the gold postindustrial billion" drags, as the weight standing, some billions in industrial and traditional society, and these billions try to be integrated by all possible ways into a postindustrial society, bringing there culture, traditions and religion. But how much can it all correspond to the requirements of a postindustrial society, and in respect of reproduction of the postindustrial blessings?

The above-mentioned "labour transformation in creativity" is regarded by some scientists as an extremely radical key, as a problem of "labour overcoming" ("the labour end"). In this connection, it is possible to refer to V.L.Inozemtsev's following reasoning, for example: "Transition from the activity caused by economic necessity to one - free from similar system of stimulus, can be designated as transition from labour to creativity. Thus if to understand creativity as internally motivated rational activity, it appears that to define activity as creativity can only its' subject. Labour overcoming [defined by us A.O., F.A.] occurs, first of all, on a socio-psychological level; and as labour process sets variety of fundamental economic events and laws, it is possible to assume that the overcoming of economic bases of society is carried out not through transformation of social structures, but owing to spiritual and intellectual evolution of people making them" [7. P.164].

We would prefer to refrain from so radical conclusions here. Transformation of labour into creativity does not mean "labour overcoming" or its "end" at all. After all creativity 
(creative activity) is also labour, and labour frequently more intense and expensive, than usual labour. Therefore, we are ready to repeat the thesis, which has been discussed since the beginning of this article: the society cannot exist without labour; labour is the fundamental, intrinsic characteristic of human existence and human activity. However, there are not eternal truths in social sciences, and deep transformations of a society in the future, connected with change of its essence, can call into question even this thesis.

\section{CONCLUSION}

So, what conclusions can be made of our work?

First, categorical analysis in economic science, especially if it is conducted in an interdisciplinary context (i.e. with attraction of the data not only economy, but also other disciplines - sociology, philosophy, political science, anthropology, etc.), considers economic institutes as socioeconomic ones; it is not simply desirable, but an essential necessity for all economic science as a whole.

Secondly, the consideration of "money" as a socioeconomic category opens wide research horizons of this institute as an original "mediator" of the modern society especially in conditions of so-called "financomics".

At last, thirdly, "labour" as a socio-economic category also should be put in a global context of the political economic and multidisciplinary analysis that will promote more understanding of labour as a specific business factor among other factors.

\section{REFERENCES}

[1] Anthology of Contemporary Philosophy of Economy, Moscow: INFRA-M, 2010.

[2] Antonovskij A.Y. Socio-Epistemology, Moscow: IFRAN, 2011.

[3] Arneson R. What is wrong with Exploitation? // Ethics, vol.91, No.2, P. 202-227. 1981

[4] Cohen G. History, Labour and Freedom, Oxford: Oxford University Press, 1988.

[5] Economic Theory (Ed. By J.Eatwell, M.Milgate, P.Newman). Moscow: INFRA-M, 2004.

[6] Ehrenberg R., Smith R. Contemporary Economics of Labour, Moscow: MSU, 1996

[7] Inozemtsev V.L. Contemporary Post-Industrial Society, Moscow: Logos, 2000.

[8] International Acts on Human Rights: Collection of Documents, Moscow: Urait, 1998.

[9] Kymlicka W. Contemporary Political Philosophy, Moscow: VSE, 2010.

[10] Locke J. Works, Vol.3, Moscow: Mysl', 1988, vol.3.

[11] Orekhov A.M., Akhmedov F.N. Economics and Contemporary Philosophy of Money: the Lessons of Crisis // Vestnik RUDN ("Ekonomika"), Moscow: vol.2, P.5-12. 2013.

[12] Polanyi K. Selected Works, Moscow: Territorija Buduscshego, 2010.

[13] Roemer J. Free to Lose: Introduction to Marxist Economic Philosophy, Harvard, Y.Harvard University Press, 1988.

[14] Schefner V. A Girl near Precipice, Moscow: Znanie, 1991.

[15] Sklovskij K.I. Property in Civil Law, Stavropol': Juzhnoje Kommercheskoe Izdatel'skoe Partnerstvo, 2000.

[16] Veblen N. Theory of Leisure Class, Moscow: Progress, 1984.
[17] Zarubina N.N. The Sociology of Economic Life, Moscow: Logos, 2006. 